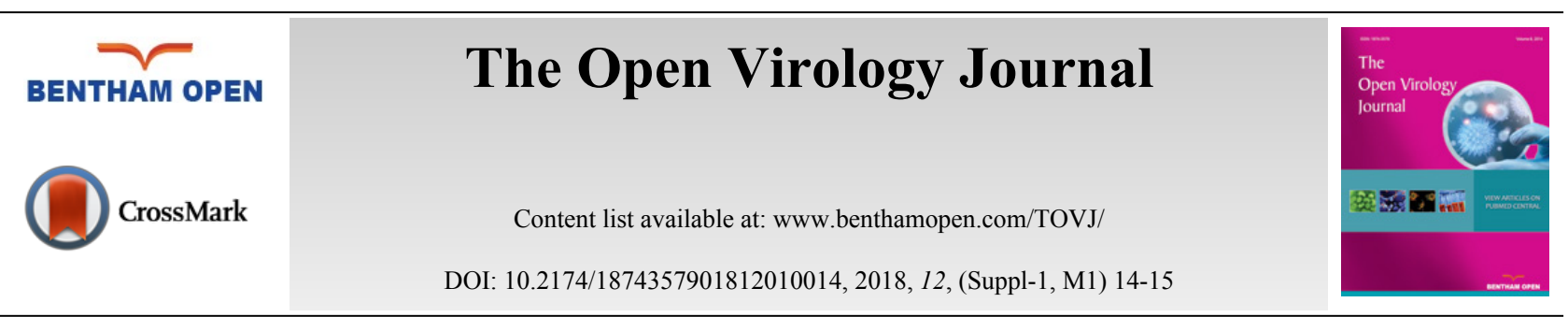

EDITORIAL

\title{
Viral Replication and Progression of Cancer
}

\section{AIMS \& SCOPE}

It has been widely established that several virus infections are strictly correlated to cancerogenesis and may induce, through their reactivation, severe damages during chemotherapy treatments. For example, the direct role that Hepatitis $\mathrm{B}$ virus (HBV), plays in the development of liver cancer is well known. Nevertheless, in other cases, as Hepatitis C virus (HCV) or Hepatitis Delta Virus (HDV) the direct role of viral replication in cancer progression is still controversial, especially in some areas, like Italy, where these infections are endemic.

The aim of this project is to update the epidemiological status of the incidence of HCC in Europe and HCV and HDV infection, with special attention to the changes during the time of route of transmission, and also investigate the interaction between viral reactivations and tumors.

\section{HCV AND HEPATOCELLULAR CARCINOMA: PATHOGENETIC MECHANISMS AND IMPACT OF} DAA'S

Ivan Schietroma ${ }^{1}$, Giuseppe Corano Scheri ${ }^{1}$, Claudia Pinacchio ${ }^{1}$, Maura Statzu $^{2}$, Arnolfo Petruzziello ${ }^{3}$

${ }^{1}$ Department of Public Health and Infectious Diseases, "Sapienza" University of Rome, Rome, Italy;

${ }^{2}$ Department of Molecular Medicine, Laboratory of Virology, "Sapienza" University of Rome, Italy;

${ }^{3}$ Virology and Molecular Biology Unit, Department of Pathology, Istituto Nazionale Tumori- IRCCS Fondazione G. Pascale, Naples (Italy)

Corresponding author: Giuseppe Corano Scheri

(giuseppe.coranoscheri@uniroma1.it ; +393896943773)

\section{EPIDEMIOLOGY OF HEPATITIS B VIRUS (HBV) AND HEPATITIS C VIRUS (HCV) RELATED HEPATOCELLULAR CARCINOMA}

Corresponding author: Arnolfo Petruzziello

Virology and Molecular Biology Unit, Department of Pathology, Istituto Nazionale Tumori- IRCCS Fondazione G. Pascale, Naples (Italy)

E-mail: a.petruzziello@istitutotumori.na.it

\section{DETERMINING THE ACTUAL PREVALENCE OF HEPATITIS B IN KHYBER PAKHTUNKHWA- PAKISTAN: A META-ANALYSIS}

Najeeb Ullah Khan ${ }^{1}$, Ali Zalan ${ }^{1}$, Arnolfo Petruzziello ${ }^{3}$, Iftikhar ud din², Fazle Haq ${ }^{2}$, Yousaf Hayat ${ }^{2}$ Pakistan

${ }^{1}$ Institute of Biotechnology and Genetic Engineering (Health Division), The University of Agriculture Peshawar,

${ }^{2}$ Department of Mathematics, Stats \& Computer Science, The University of Agriculture Peshawar, Pakistan

${ }^{3}$ Virology and Molecular Biology Unit "V. Tridente", Department of Pathology, Istituto Nazionale Tumori- IRCCS 
Fondazione G. Pascale, Naples (Italy)

Corresponding author: Najeeb Ullah Khan ${ }^{1}$

E-mails: najeebkhan@aup.edu.pk,naji_banni@yahoo.com

\section{Guest Editor (s)}

Arnolfo Petruzziello

Virology and Molecular Biology Unit

Istituto Nazionale Tumori

IRCCS Italia

Fondazione G.Pascale

80131, Via Mariano Semmola

Naples (Italy)

Tel: +39 0815903433/373/ 1779

Fax +390815903854

E-mail: a.petruzziello@istitutotumori.na.it

(C) 2018 Arnolfo Petruzziello.

This is an open access article distributed under the terms of the Creative Commons Attribution 4.0 International Public License (CC-BY 4.0), a copy of which is available at: https://creativecommons.org/licenses/by/4.0/legalcode. This license permits unrestricted use, distribution, and reproduction in any medium, provided the original author and source are credited. 